11001

Notes on the thysamoptera

of North America with

descriptions of mew species

Entomology

A. B.

1910

\section{8}

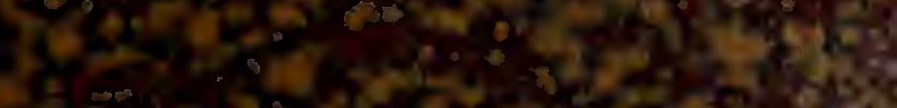

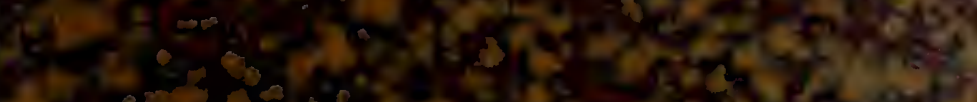

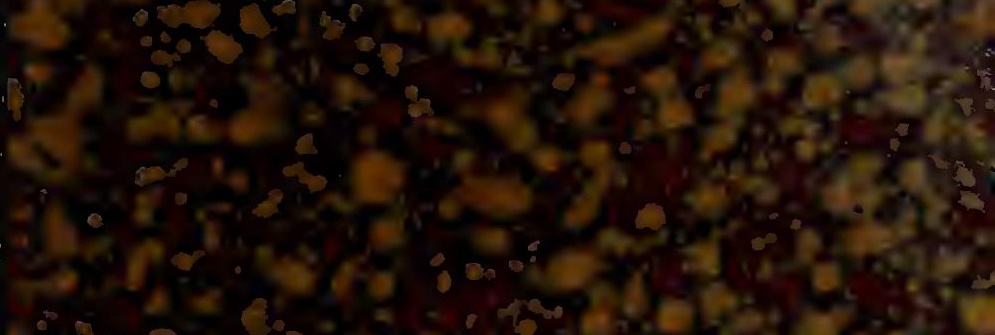

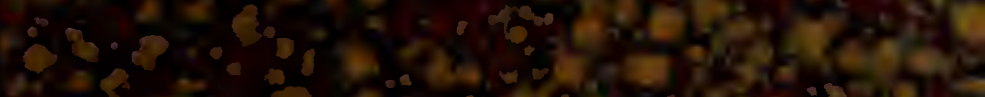

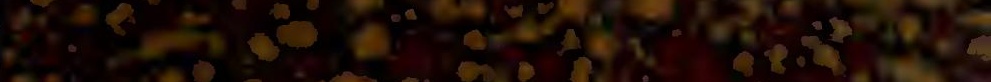

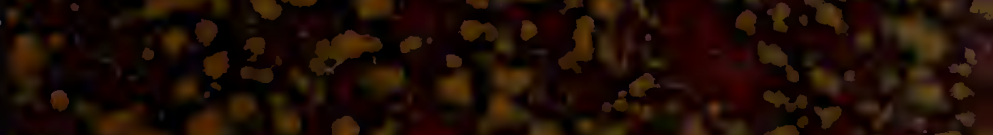

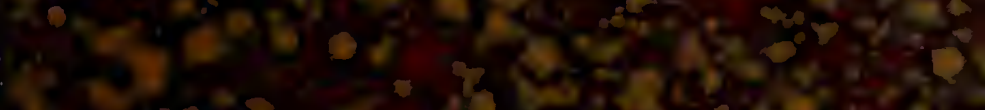

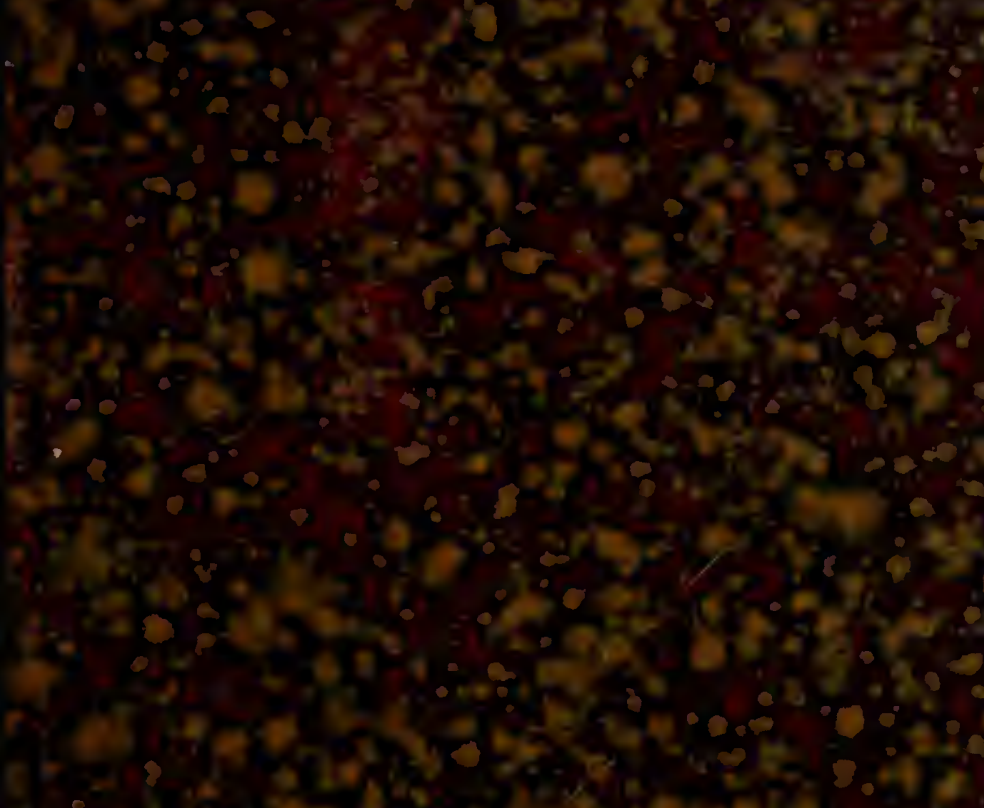

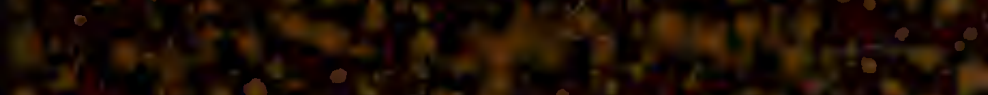

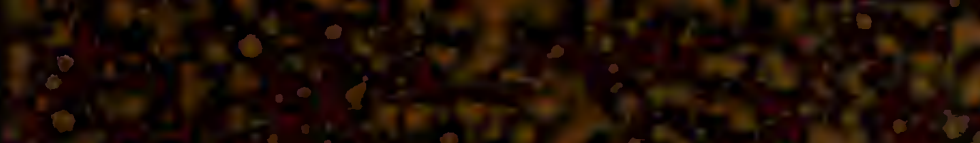

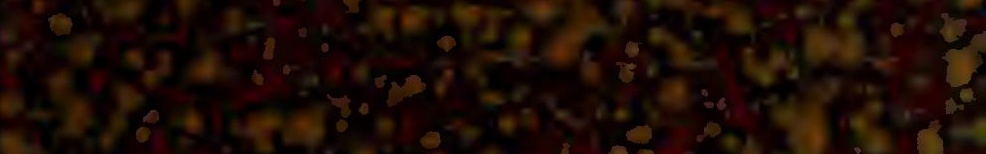

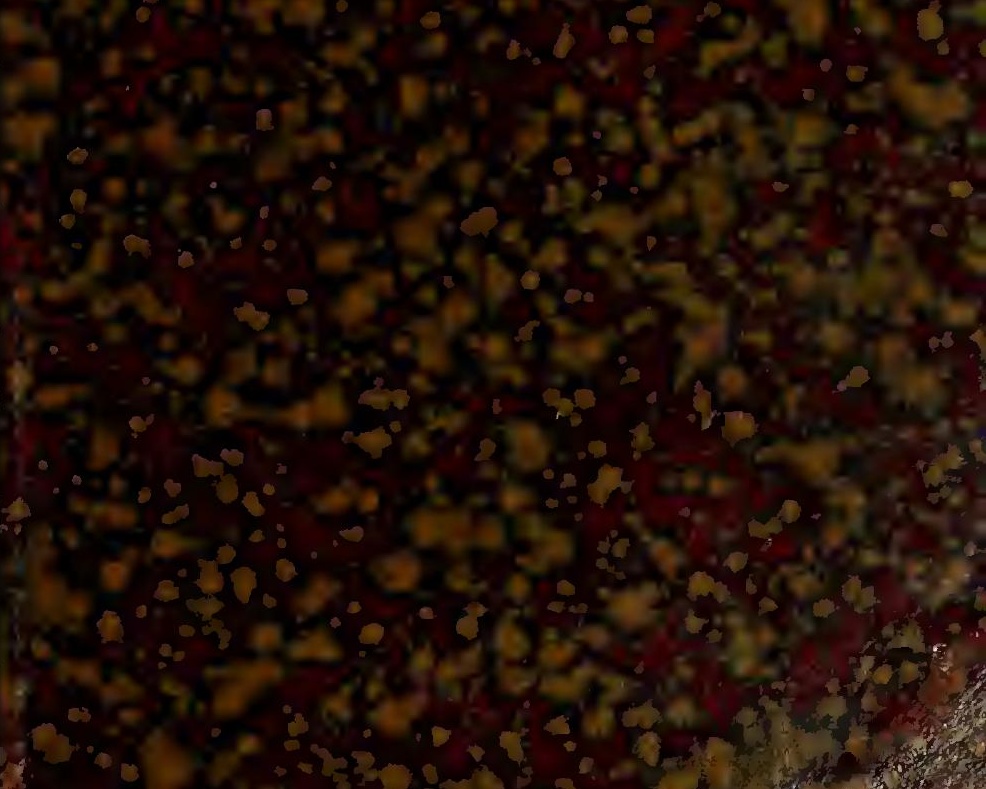


UNIVERSITY OF ILLINOIS

LIBRARY

$\begin{array}{ll}\text { Class } & \text { Book } \\ 1910 & \text { H76 }\end{array}$ 




\title{
NOTES ON THE THYSANOPTERA OF NORTH AMERICA WITH DESCRIPTIONS OF NEW SPECIES
}

\author{
by \\ Josoph Douglas Hood
}

Thesis for the Degre日 of Bachelor of Arta

in General Science

in the

COLLEGE OF SCIENCE

of the

UNIVERSITY OF ILLINOIS

June $1,1910 . \mathrm{m}$ 
Digitized by the Internet Archive in 2013 


\section{UNIVERSITY OF ILLINOIS}

June 1

1910

THIS IS TO CERTIFY THAT THE THESIS PREPARED UNDER MY SUPERVISION BY Jose ph Douglas Hood

ENTITLED. NOTES ON THE THYSAIOPTRRA OF NORTH A3ERICA

WIIH DFSCRIPLTONS OF NEM SPECIFS

IS APPROVED BY ME AS FULFILLING THIS PART OF THE REQUIREMENTS FOR THE

DEGREE OF_.... Bachelor of Arts

in General Science<smiles>CCCCCCCCCCCCO</smiles>

APProved: 0 a $a$ tra

HEAD OF DEPARTMENT OF.

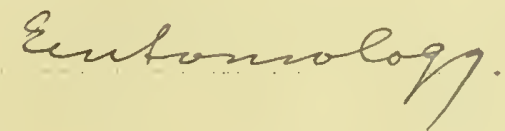




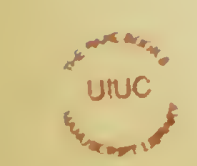




\section{I $\underline{\mathbb{N}} \underline{\mathrm{T}} \underline{\mathrm{R}} \underline{\mathrm{D}} \underline{\mathrm{U}} \underline{\mathrm{C}} \underline{\mathrm{I}} \underline{\mathrm{I}} \underline{\mathrm{O}} \underline{\mathrm{N}}$.}

I first became interested in Thysanoptera four years ago, in the fall of 1906, and the first specimen which I ever collected was a female of AEolothrips bicolor, found hibernating under an old railroad tio near Champaign, Illinois. Not knowing what the insect was, I brought it to the laboratory for determination. When I found that the species had boen discovered for the first time only four years previous, in Massachusetts, and that no records of its capture had been made since, my interest was aroused and I mounted the specimen carefully in balsam. I did not dream that the finding of species new to science would be possible, but I felt certain that I could by careful collection, add materially to the known geographical distribution of the several known forms. With this idea in mind, I began the collection of thrips. From a single slide of a fragmentary specimen of AEolothrips bicolor, my collection grew rapidly, until now it contains more species from the state of Illinois than are describod from all North America.

The study of Thysanoptera is of especial interest not because the insects are of any great economic importance, but rather because the group is relativoly unknown and the possibilities of interesting discoveries infinite. This furnishes a mysterious and fascinating attraction, ana the insects themselves make delicate and beautiful mounts, which are absolutely safe from the attacks of museum pests, easily filed away, and as nearly permanent as any collection can be.

Very little work has been done on the Thysanoptera of North America. Scattered papers have appeared now and then in which a fow new species were described, and no really comprehensive monograph 

has ever been written. A paper by Dr. Warren Elmer Hinds, published in the twentysixth volume of the Proceedings of the United States National Museum, is the closest approximation we have to a general work. In it are described all the species known previously to 1902-thirty seven in number, of which eighteen are new. When we find that nearly all of these eighteen forms new to science were collected by one man within a radius of a two miles from the Massachusetts Agricultural College, we begin to realize the deficiency of our knowledge of the New World species when the vast areas of Western United States and Central and South America remain unexplored.

In 1896, six years before the publication of Hinds' paper describing the Mas achusetts species, Miss Alice M. Beach described a few species from Iowa. And since 1902, the species of California have been studied by Moulton, Crawford and Daniel; those of Michigan by Shull, and those of Illinols by Hood. This is all the mork that has been done on the group in North America. 



\section{DIRECTIONS FOR THE COLLECTEON OF THYSANOPTERA.}

Owing to the small size of these insects and the consequent difficulties of collection and preservation, the few suggestions given below may prove useful to the amateur Thysanopterist. When I first became interested in this group, tho lack of full directions for collecting and preserving specimens did much to hinder the progress of my work. * It was largely through experience that I was enabled to tell where to look for specimens, and how to mount them after they have been collected. The following suggestions are consequently the results of personal experimentation. They are presented with the hope that the beginner will rind among them hints which will better direct his attention to places of collection, and which will save him a portion of the neodless labor which always falls to the lot of the amateur-- labor which he $e^{-1}$ in the future consider ili-directed.

This chapter is naturally divisible into two parts: first the collection of specimens, and secondly, their preservation for future study after they have been brought to the laboratory.

The order Thysanoptera as a whole has an extensive environmental distribution. Species occur in flowers, in grass, or on the leaves and branches of trees; some live in galls, turf, fungi, or moss, or under loose bark, on living or decaying trees; while still others may be found under fallen leaves and in similar decomposing plant remains. Each of these species, however, is usually confined to a particular habitat * or class of habitats, outside

* The chapter on this subject by Dr. Uzel in his" "Monographie der ordnung Thysanoptera" was at that time inacessible to me, being written in his native tongue, Bohemian.

* The word habitat has been used by several entomologists as a synonyn of distribution. The habitat of a species, in the sense in which it is used by ecologists, is that particular situation in which it finds all the conditions necessary to its successful growth and reproduction. It is the situation where all the ocological factors, - clinatic and edaphic, biotic and physical, - are favorable to the species. The habitat of Eurythrips ampliventralis Hinds is thus turf, and not "Amherst, Massachusetts", as given by its original describer. 
of which it normally never occurs*. We thus have one species $* *$ which is found only in phylloxera galls on hickory; another *** only in galls on pin oak; a third*** only in flowers of jack-in-the-pulpit, while a fourth ***** never occurs outside of the moss iringes the bases of our forest trees.

This large variety of situations in which he must search for species makes the collector dependent upon a rather extensive collecting apparatus. The special apparatus which he will employ when collecting in each of these particular habitats will be described below. The general outfit which he will need at all times consists essentially of vials, paper bags, a chisel or stout knife, a dmall camel's hair brush, and a vasculum or other receptacle in which to carry them.

Vials of about two drams capacity are recomended. The corks should be free from all irregularitios which might afford shelter to the specimens and cause them to be subsequently overlooked. Care should be taken also that the corks do not project past the neck of the vial; otherwise any specimens which might cling to the sides of the cork are likely to be crushed against the neck of the vial when the cork is extracted. The observance of these seemingly slight particulars will save many a specimen. Papar bags are used to bring flowers, galls, moss, etc., into the laboratory from the field. When filled, they should be securely fastened by means of a stout paper clip, or a rubber band. Specimens are transferred to vials by means of a small, well-pointed, camel's-hair brush. When picking up the specimens, care should be taken that it, is not injured. This may best be accomplished by lifting it upon the yip of the moistened brush.

* Species which occur commonly under the bark of trees, in galls, or in other secluded situations, may, however, sometimes be taken in sweeplings from herbaceous plants. But as very fow individuals of a species are ever taken at any one time in such situations, and as all such individuals are long-winged, we conclude that they are merely engaged in the dissemination of their species, and are in search of suitable places for the deposition of eggs. Trichothrips americanus Hood furnishes an excellent example. This species is normally shortwinged, spending its life under the loose bark, decaying, fungusgrown stumps, where it would have no use for wings even if it had them. In early Summer, long-winged individuals occur. It is this generation upon which the species is dependent for any extension of 1 ts distribution. On a sultry afternoon when the barometer is low and heralding the approach of a strom (a time when insects are unusually active) a few "sweepings" with a suitable net will frequently yield an individual or two of the long-winged form of this species. Dr. Uzel torms the macropterus fomales of such species the "femininae disseminatus", showing that he fully appreciated their significanco.

* Liothrips caryāo Fitch.

*** Phlogothrips sp. nov.

**** Heterothrips arisaemae Hood.

***** Lissothrips muscorum Hood. 

The brush should never be brought directly down upon the insect.

I have omployed two general methods for making miscellaneous extensive collections,-- collections in which quantity of material, rather than accuracy of ecological data, is desired. The first consists in "sweeping" grasses and other herbaceous plants with a strong sweep-net of fine mesh. The bag of this net should ne of India linen and attached to the ring with a copper wire. The ring should be of thick galvanized iron wire and soldered into a ferrule to which a strong handle is attached. This net may be used to great advantage at all times, and will yield more species than any other single method. - The second nethod is as follows:- a sheet of canvas about a yard square is sewed in the form of a bad, open at one end. Two sticks exactly equal in length to the diagonals of the bag are fastened together at the middle by means of a single nail, to form an $X$. These sticks are insorted into tho bag, and their onds spread out and secured in corner pockets, formings a piece of apparatus sufficiently rigid and light to be held by one hand in any desired position. By means of a stout stick, Thrips may be jarred on to it from the leaves andbranches of trees and shrubbery. The material 90 secured is usually more valuable than that obtained in any other way, owing no doubt to the slight amount of attention which has been devoted to the collection of tree-inhabiting species.

Species which occur under the loose bark on living or dead trees may be secured by prying off the bark and either sifting it with a sieve of large mesh, or by examining both the loosened bark and the exposed surface of the treo* with a hand lens. Species collected under bark during the minter are usually short-winged, while those taken in the summer are usually long-winged. Winter collecting will yield all those species which pass the Summer in such situations, and in addition, will furnish those which are there merely for hibernation and which seek other habitats upon the advent of warm weather in the spring.

Gal1s, flowers, or fungi which contain Thrips may be brought to the Iaboratory in small paper bags and pulled or cut apart over a background of white paper. Nymphs or"pupáe"** are more commonly found in galls than are adults. It seems that the nymphs when

My experience in collecting from such situations shows that a vastly larger number of individuals cling to the tree than to the bark. If the tree is loose or disposed in flakes, they appear always to be found on the ventral surface toward the center of the tree. The explanation which suggests itself is simple: Thrips in search for protective quarters crawl about over the side of the tree and when a suitable oponing in the bark is encountered. squeezo into the crevice until their body comes into close contact with the opposed surfaces. As all such species are flattened dorso-ventrally, they cannot turn over, and as a consequence must remain in the position in which they enter the crevice. We might carry this even further, and reason that the hibernating species craml up from the base of the tree and do not descend from the crown, because they are always found below the area of attachment of the bark affording them shelter.

* Insects with an incomplete or direct metamorphosis do not,
strictly speaking, have a pupal stage. The term is a convenient one, however, in this connection. 
when they have about attained their complete development, enter the gall in order to safoly pass the quiescent "pupal" stago. Nymphs or "pupä" so taken may usually be reared with iittle difficulty to the adult stage by putting the galls into a vial or bottle, and taring care merely to preserve the necesarry humidity.

Species which occur under fallen feaves, in decomposing plant remains, or in turf, may be collected in any one of three ways. (1) The material to be searched may be brought to the laboratory and carefully pulled apary and scmutinized over a sheet of white paper. (2) Or it may be sifted in the field, and only the siftings brought in to be searched. (3) This method is a more exhaustive one, and has been employed with marked success by Professor Antonio Berlease, an Italian arachnologiat. * It is especiaily valuable for the collection of hibernating species. It consists essentially in usuing a specially constaucted tin tank which is open at one end and has a small hole in the middle of the opposite end; within this tank is fitted a tin funnel in such a way that a space is left surrounding it which can be filled with water. Across the top of the tank is supported a screen, on which is placed the debris which is supposed to contain Thrips. Water is placed in the outside portion of the tank, and a receptacle of some sort is put under the opening of the funnel. When heat is applied to the water of the outside tank, the insects, mites, and other arthropods in the debris are incited to activity, and they scurry about, falling into the funnel which directs them into the receptacle at its lower end. The specimens may be collected alive in a dry vial, or in alcohol. For Thrips, the former method is recomended.

* Seo Entomological Nows. Vol. , p. . 



\section{ECONOMIC CONSIDERATION:}

The Importent Injurious species of the State of Illinois.

Small and apparently insignificant though the thrips are, they cannot be disregarded from an economic standpoint. Only a fer species, to be sure, must be considered as decidedly injurious, but these are widespread in their distribution and difficult to control. Doubtless much damage, really caused by these tiny foes, is ascribed to more conspicuous but less injurious insects.

Before any preventive or remedial measures are to be taken, then, one should make sure that he is really dealing with a species of thrips. This is not at all a difficult task if one is provided with a strong hand lens or a compound microscope, for these insects are the only ones with a delicate fringe on all four wings, and with tarsi or feet that have at their tips a proturusible bladder-like organ which, though made slightly adhesive bt a secretion from glands in the foot, deponds largely upon suction for its successful operation.

These characters, though the only perfectly satisfactory ones, are not visible to the naked eye; and so the farmer or gardener will find it necessary to familiarize himself with their general appearance. This is not very difficult, for thrips are exceedingly abundant in Summer, fairly swarming in many species of flowers in our gardens and greonhouses, and on our farms. If almost any flower be carefully examined, minute, linear, slender insects, yellowish or brownish in color and about one thirty-second of an inch in length, will be se日n running about and jumping, in a frantic at tempt to escape. These are thrips. Folded along their backs while they are at rest are two pairs of delicate, linear wings, fringed around their edges with numerous fine cilia or hairs. Weak though these wings appear, they are really 
capable of supporting the insect in sustained filight.

In foeding, the thrips usually move parallel to the veins of the leaf. The green parts of the plant, chiefly, are punctured by the lacerating, spine-like mandibles which are completely enclosed within a beak-like mouth-cone attached to the ventral or under surface of head; the sap is then withdrawn by suction. The emptied plant cells become white and shrivelled as they dry up, and as the insect moves on to fresh cells, the traces of its feeding are show by irregular streaks of dry, whitened cells. Behind them, as they feed, they leave a row of dark colored dots of excrement, which are sometimes mistakn for eggs. There is thus no chewing of the plant tissues; the cells are simply punctured and their juices removed, the damage appearing in the form of whitish streaks and spots.

If a female of one of our common plant-loving species be carefully watched while it feeds, it may often be seen to deposit an egg. This is done by means of a hollow, saw-like ovipositor composed of four closely fitting plates. It is analogous to the sting of the honey bee, and is inserted through the plant epidermis, usually in a place where the mouth parts have first weakened the tissue or broken entirely through 1t. An egg is conducted through the cavity between the plates and deposited beneath the epidermis. The softest and tenderest parts are always chosen for deposition, for their is danger of the ovipositor getting caught if the tissue is hard. Also it is necessary during egg developement that the surrounding tissue be flexible and moist, for the egg covering is elastic and the embryonic thrips within increases in size very noticealy before the larva issues. After about four days, the young larva issues from the egg and feeds voraciously on the plant juices for a period varying in length from about four days to more than three weeks. It then seeks some 

secluded spot, often below the surface of the soil, and goes into a pupal or resting stage. From this the adult insect may emerge in as short a period as two days, or as long a period as several months, depending on the species in question and the time of the year. There are always four stages-- egg, larva, pupa, and adult, covering from one. to many weeks, -- and in all except the first, great damage may be done to the food plant by the extraction of sap. As each female normally lives for several weeks, and during all this time is busily engaged in depositing eggs which successively produce other females, the increase in numbers is very rapid and the injury to the food plant great.

In IIIinois, we fortunately have only four or five species of thrips which are decidedly injurious. Each of these will be briefly discussed in turn.

THE ONION THRIPS. (Thrips tabaci Lindeman).- This is ane of the most injurious species of thrips known, because of its great numbers and wide distribution. It is quite active, about one thirty-second of an inch long, and of a pale yellowish color. Itslattacks are largely confined to onions, cabbages, and greөnhouse plants.

A spray of kerostine emulsion is recomended as the cheapest and most effective method of controliing this pest. It should be used at the strength of one part of the stock to ten parts of water.*

If the plants attacked are in a greenhouse, fumigation will often prove more satisfactory. The use of hydrocyanic-acid gas is recomended. This gas is exceedingly poisonous, and should not be employed until one has thoroughly familiarized himself with its use.

* Full and detailed directions for preparing and using this spray are given in Circular 80, Bureau of Entomology, U.S. Department of Agriculture. It may be obtained upon application to the secretary of Agriculture, Washington, D. C. 

The work must be conducted at night, and the plants should have dry follage. Use from 0.01 to 0.05 grams of Potassium cyanide per cubic foot for from two hours to all night, the strength and length of exposure varying accoraing to the tightness of the house and the kinds of plants treated, as there is considerable difference between various plants to their resisting power to this gas."

THE WHEAT THRIPS. (Euthrips tritici Fitch.).- This insect is about one thirty-second of an inch in length, and is of a pale orange yellow color. It is the most abundant species of thrips in the state, occuring on almost every species of plowering plant. It is not quite as injurious as the onion Thrips, however, for its attacks ate less confined to cultivated plants; it is very common in many kinds of flowers and on grasses and cereals.

By far the greatest amount of damage seems to be done to strawberries, in the blooms of which they swarm, and by their punctures of the essential parts of the flower they prevent its fertilization and the consequent developement of the fruit. This failure of bloom, though perhaps also produced by other insects and in other ways, is known to growers as "buttoning". The most serious injuries have been reported ftom florida and Illinois. In dry seasons, the strawberry crop has been reduced to one third in some sections.

The best treatment, as in the case of the onion Thrips, seems to be a spray of kerosine emulsion. "Rose-jeaf Insecticide"-- a high grade extract of tobacco-- is another excellent practical remedy when used with 48 parts of water.

THE GRASS THRIPS. (Anaphothrips striatus Osborn.)-- This species is about the same size as the two preceding, and of a pale yellow color, with a shading of black. Its injury is entirely confined to *See Circulars 37 and 57, Bur. Ent., U. S. Dep't. Agri. 

grasses. The most conspicuous effects of its work are the dead tops of June grass and timothy, known commonly as "Silver top" or "White top". This is caused by the abstraction of sap from the tender axial stems, thus cutting off the supply of sap to the head, which therefore fails to bear se日d. In the case of wheat, rye, ozts, $\theta$ tc., this and the preceding species suck the milk directly from the growing kernels in the ear and produce an abortive condition of the head.

As the female hibernates above ground, burning in early spring will destroy large numbers of them. As the damage is most sever $\theta$ on worn out meadows, fields, and lawns, fertilization and early harvesting will also be effective.

THE GREENHOUSE THRIPS. (Heliothrios hämorrhoidalis, and H. femoralis.)- These species do little damage in this state, but in the east and in the old World their injuries are of prime importance. The same remedies may be used as recomended for the onion Thrips. Both these greenhouse species are slightly larger and stouter than the preceding species, and are nearly black in color. 



\section{$\underline{\mathrm{S}} \underline{\mathrm{Y}} \underline{\mathrm{S}} \underline{\mathrm{T}} \underline{\mathrm{E}} \underline{\mathrm{M}} \underline{\mathrm{A}} \underline{\mathrm{T}} \underline{I} \underline{\mathrm{C}} \quad \underline{\mathrm{P}} \underline{\mathrm{A}} \underline{\mathrm{R}} \underline{\mathrm{T}}$.}

Key to the sub-orders.

I. Female with a saw-like ovipositor. Last abdominal segment of female conical; that of male sometimes like that of female, but more frequently broadly rounded. Wings with numerous microscopic spines; fringing hairs jointed at their insertion into the wing membrane; fore wings with at least one vein extending from base to tip of wing.

Sub-order Terebrantia.

II. Female without an ovipositor. Last abdominal segment tube-like in both sexes. Wings without microscopic spines; fringing hairs not jointed at their insertion into the wing membrane; fore wings with a single rudimentary vein, extending from base to near middle of wing.

Sub-order Tubulifera. Represented only by Fam. Phlöothripidâ. 



\section{SUB-ORDER TEREBRANTIA.}

In this sub-order belong all the more active species of Thysanoptera, and those which are of the greatest economic irnportance. They are usually smaller than the Tubulifera, are often quite highly colored. The Onion Thrips, the Pear Thrips, the Greenhouse Thrips, the Tobacco Thrips, and a host of other injurious species belong here. Because of the ecunomic importance of this group, they have been more extensively studied than their relatives the Phloeothripidae, this resulting frequently in a multiplication of scientific names, a confusion of the species, and a consequent difficulty of taxonomic work. as follows:

The Terebrantia are divisible into two distinct families,

Key to the Families of Terebrantia.

A. Antennae always nine-segmented. Wings of both pairs broad and rounded at tips; fore wings with cross veins. Ovipositor curved upward.... Family AEOLOTHRIPIDAE.

AA. Antenna usually $6-8$ segmented, very rareiy 9- segmented. Wings narrow and pointed at tips; fore wings without cross veins. Ovipositor curved downwards.... Family THRIPIDAE. 



\section{Family $\widehat{\text { AEOLOTHRIPIDAE} . ~}$}

This family includes the most primitive Thysanoptera

known, as is shown by the nine-segmented antennae, the broad veined wings, the absence of antennal sense-cones, etc. They are all moderately active species, and feed almost entirely in the flowers of plants.

A. Antennaie strongly geniculate, with the tip of second segment strongly produced inwardly beyond the insertion of the third.

Ankothrips Crawford.

AA. Antennầ not geniculate; second segment not produced beyond insertion of the third.

a. Maxillary palpi seven or eight-segmented; labial pelpi 4-or 5-segmented. Ninth abdominal segment of males not prolonged into hooked clasping organ.

Orothrips Moulton.

aa. Maxillary palpi three-segmented; labial palpi four-segmented.

b. Head very large, swollen, hemispherical, widest at posterior margin, compactly united to prothorax. Fore wings widest near base. Oncerothrips. gen. nov.

bb. Head small, sub-rectangular, para$11 \theta 1$ sided, not at all united to prothorax. Fore wings widest aplcally.

Genus ANKOTHRIPS Crawford, 1909.

Ankothrips Crawford. Pomona College Journ. Ent. Vol 1, No-4 Dec. 1909, p. 100.

Dic log/ polnische Ekebniks einer Forschungsreise im westlitchen un zentralen̂ Südafrika, ausgeführt in dem Jahren 1903-05. Vierter Band. Erste Lieferung. 

In this recently described genus I place Ankothrips robustus Crawford and DiEaratothrips fisgidens Trybom. The former was described from California where it was taken on the California Laurel and the California Lilac, while the latter occurs in the flowers of the "Pferdebuschen" in Klein- 



\section{Genus $\widehat{\text { AEOLOTHRIPS. }}$}

Three readily separable species of this genus occur in Illinois, as follows:

A. Wings cross-banded.

a. Abdominal segments 2 and 3 with a transverse white band. ............ bieolor

Hinds.

aa. Abdominal segments 2 and 3 concolorous with remainder of abdomen. ....... fe. fesclatus

$(\operatorname{Iinn} \theta)$

B. Wings pale, with a longitudinal black band

along posterior margin. AE. hartii Hood, MSS .

AEOlothrips bicolor Hinds.

AEOlothrips bicolor Hinds. Proc. U.S. Nat. Mus. Vol. XXVI, No. 1310, 1902, p. 130.

A very common native species in the flowers growing along the roadsides of Illinois.

\section{AENlothrips fasciatus (Linne).}

Another common species, frequently found associated with the preceding one in similar situations. Probably introduced from Europe.

AEolothrips hartil Hood: MSS. Common on locust trees at Havana, Illinois. 

Genus OROTHRIPS MOUIton, 1907.

Bul1. U. S. Dept. Agr., Bur. Ent., Tech. Ser., No. 12, part III, p. 45.

Head slightly wider than long. Antennâ nine-segmented, moderately slender, all segments freely movable, but the apical four somewhat more closely united than the others. Maxillary palpi seven- or eight-segmented; labial palpi four-or five-segemnted. Prothorax wider than long, usually slightly longer than head; posterior margin sometimes with strong spines. Fore tibiâ unarmed; fore tarsi with the usual hook-1ike appendage. Wings broadened distally, where they may be twice as broad as at basal third. Wings of first pair crossbanded in both the known species. Ninth abdominal segment of male not prolonged at the posterior angles into hooked, clasping organs.

I have preferred to extend the description of orothrips to include the species described below rather than to erect a new genus for it, for the reason that the differences between my specimens and Moulton's diagnosis may possibly be more apparent than real, and due partly to inaccuracies of observation and description. I am led to this conclusion by the statement in the original description that all the tibiae of orothrips are armed. A comparison of Moulton's figure (PI. I, fig. I) with that given by Uzel on Tab. V, fig. 38 of his Monographie will show that such is not the case. 
Female.- Length about $1.6 \mathrm{~mm} .(1.47-1.77 \mathrm{~mm}$.$) . Color testaceous,$ prothorax with an indistinct V- shaped, brown cross-band at middle of dorsum; head and prothorax slightly darker; abdomen with a faint indication of a pale cross-band on segments 1, 2, and 3; antennal seg:ments 1-4 pale yellowish white, remainder of antenna black.

Head about one and one-fourth times as wide as long, roundly angulate between antennâe, and slightly shorter and narrower than prothorax; cheoks slightly arcuate; dorsal and lateral surfaces faintly transverse striate, set with numerous minute spines. Eyes large, pilose, prolonged on ventral surfaces, and with large, distinct facets. Ocelli large, equidistant. Antennée moderately slender, about as long as combined lengths of head, pro- and mesothorax, the last four segments united into a more or less compact club; segment 1 broadest, nearly as wide as long, "tapering apically; 2 distinctly longer and nárrower than 1; 3- 6 long, cylindrical, successively decreasing in length 4 distinctly shorter than 3; 7 slightly longer than 6, usually about equal to 5 in length and narrowing apically; 8 abruply shorter, one-half to one-third as long as 7 , and twice to five times as long as 9 , which is sub-concave and usually about as long as wide. Segments $1-4$ pale yellowish white, 3 and 4 sightly more whitish; 4 clowded apically with black; 5- 9 uniform black. Segments 3-9 quite thiekly clothed with short, white, inconspicuous hairs of uniform length; 5, 6, and 7 each with a short,linear, pale, sensory area on ventral surface.* Maxillary palpi eight-segmented; labial palpi four segmented. Ventral surface of head with two pairs of prominent spines, one of which is sub-antennal and the other of which is situated between the posterior angles of the eyes, just anterior to the chitonous thickening.

Prothorax subrectangular, slightly wider than long, and a little wider than head, sides and posterior margin slightly arcuate, hind angles broadly rounded; surface with numerous minute spines. Mesothorax broader than prothorax, anterior angles broadly rounded. Mesonotum transversely striate; metathorax narrowed posteriorly, metanotum faintly transversely striate. Wings long; fore wings expanded apically, broadest at apical sixth, where they are twice as wide as at bas al fourth; venation normal to the group; spines on anterior portion of ring vein short, slightly projecting beyond margin of wing; first and second longitudinal veins set with respectively about 20 and 14 short spines. Color of fore wings pale brom, with two white cross bands; a narrow one at basal seventh, and a slightly wider one at apical seventh; intermediate brown area somwhat paler at midale; hind wings white.

Abdomen sub-piliolate, at seventh segment twice as wide as at base and one and one half times as wide as pterothorax; posterior margin of segments 1, 2, and 3 white or whitish, segments 9 and 10

* Similar areas are almost certain to be present on segments 3 and 4 as in AEOlothrips fasciatus and $\widehat{A E}$. bicolor, but I have not been able to make them out on my specimens. 


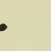


tinged with yellow or white.

Measurements: of a female from Odin, Illinois:- Length $1.73 \mathrm{~mm}$; head, length .17 mm., width. $21 \mathrm{~mm}$; prothorax, length.21 mm., width $.24 \mathrm{~mm}$; ; pterothorax, width .30 mm.; abdomen, width .47 mm. Antennãe: $1,39 \mu ; 2,48 \mu ; 3,162 \mu ; 4,141 \mu ; 5,75 \mu ; 6,62 \mu ; 7,66 \mu ; 8,23 \mu$; 9 , $12 \mu$; total. $63 \mathrm{~mm}$, width .025 mm.

Measurements: of a female from Monterey, Mexico:- Length $1.4 \mathrm{~mm}$., head, length .150 mm., width .21 mm.; prothorax, length .20 mm., width . $23 \mathrm{~mm}$; pterothorax, width . $30 \mathrm{~mm}$; abdomen, width . $35 \mathrm{~mm}$. Antennâe: 1, $33 \mu ; 2,56 \mu ; 3,132 \mu ; 4,89 \mu ; 5,67 \mu ; 6,49 \mu ; 7,52 ;$. 8, $25 \mu ; 9,14 \mu ;$ total . $517 \mathrm{~mm}$., width .025 mm.

nâe. Male.- Similar to female, but slenderer and with longer anten-

Measurements of a male from Monterey, Mexico:- Length 1.07 mm.; head, length .147 mm., width .174 mm.; prothorax, length .160 mm., width .181 mm.; pterothorax, width .245 mm.; abdomen, width $.192 \mathrm{~mm}$. Antennä: $1,36 \mu ; 2,45 \mu ; 3,154 \mu ; 4,137 \mu ; 5,92 \mu ; 6,77 \mu$; $7,78 \mu ; 8,24 \mu ; 9,8 \mu ;$ total .65 mm:, width .027 mm.

Measurments of the antenna of a male from Browngville,

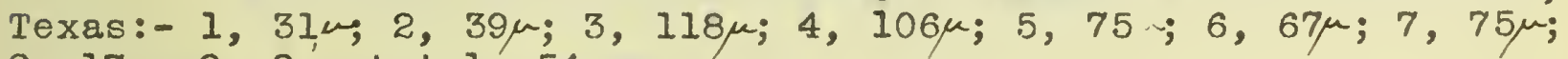
$8,17 \mu ; 9,8 \mu ;$ total. $54 \mathrm{~mm}$.

Described from several specimens of both sexes taken in aweepings by Mr. Charles A. Hart at Monterey and Matamoras, Mexico, at Brownsville, Texas, and at Odin and DuBois, Illinois, in June and July.

This species may easily be distinguished from all other eastern ÂFolothripidâe by its pale coloration and by the greater number of segments in the maxillary palpus. In at least one of these respects, however, it resembles orothrips kellogii Moulton, described from California. But it differs strongly from that species in that the maxillary palpi are eight-instead of seven-segmented, the labial palpl are four-instead of fie-segmented, and the fore wings are greatly expanded apically and twice as wide near apex as at basal third. These points of distinction may also be noted by a comparison with Moulton's figures. The strong spines on the posterior prothoracic margin of kellogil are greatly reduced in flavus, being no longer than the discal ones; the brown cross band at the middle of the fore wings is nearly twice as wide in flavus and frequently shows a tendency to form two cross bands by the appearance of a pale, central area; the ventral sensory areas on the fifth and sixth segments of the antennâe are slit-like in flavus and circular in kellogil; and the "ring vein" of the fore wings seems in Moulton"s species to be armed with slightly longer spines. 



$$
\begin{aligned}
& \text { oncerothrips gen. nov. }
\end{aligned}
$$

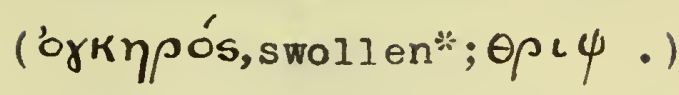

Head very large, swollen, hemispherical, widest at posterior margin, compactly united to prothorax. Antennế nine-segmented, very slender, apical segments scarcely more closely united than the others. maxillary palpi thre日-segmented; labial palpi four-segmented. Prothorax slightly wider than lorig and slightly longer than head, distinctly narrowed posteriorly, where it is three-fourths its anterior breadth; posterior margin without strong spines. Fore tibiae unarmed; second fore tarsal segment with the usual hook-like appendage. Wings very slender; for $\theta$ wings widest near base, cross-banded, apical thre日fifths of anterior margin set with long spines.

Type.- Aeolothrips vespiformis Crawford.

This genus is a very distinct one, readily separable from AEolothrips Haliday (which it should follow in a linear arrangoment of the genera) by the compactly united head and prothorax.

oncerothrips vespiformis (Crawford)

AEOlothrips vespiformis Crawford, Fomona College Journal of Entomology, Vol. I, No. 4, Dec. 1909, p. 109.

The specimen from which the original description of this species was drawn was collected in Managua, Nicaragua; I have specimens from Brownsville, Texas, collected in the summer of 1908 by Mr. Charles A. Hart.

* In reference to the unusually large head. 



\section{Genus CHIROTHRIPS Fialiday, 1836.}

\section{KEY TO FEMALES.}

I. Second antennal segment not prolonged at outer apical angle. C. hamatus Trybom.

II. Second antennal segment with a subacute prolongation at the outer anterior angle.

a. Posterior prothoracic angles with two moderately long spines.

b. First antennal segment shorter than the second and without a transverse carina; combined lengths of segments 7 and 8 about three-fifths as great as that of segment 6 . Greatest width of fore wings (exclusive of scale) five-thirds as great as the width at middle. Basal abdominal segments with a

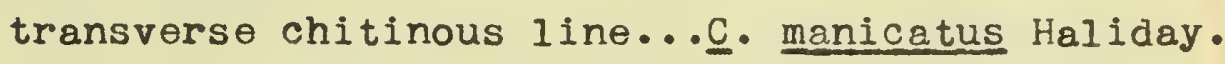

bb. First antennal segment longer than the second, with a transverse carina. Combined lengths of segments 7 and 8 about five-sixths as great as that of segment 6. Greatest width of fore wings (exclusive of scale) four thirds as great as the width at middle. Basal abdominal segments with a transverse row of about 18 small, dark brown, arcuate, chitinous thickenings at basal third.

\section{C. capriolae sp. nov.}

aa. Posterior prothoracic angles without long spines.

c. "Abdomen light yellow" (Hinds)...… obesus Hinds. cc. "Abdomen light brown" (Hinàs)..‥ crassus Hinds. 

Female.- Length about $1.1 \mathrm{~mm}$. Color blacklsh brown; segments 1-8 of abdomen often bromish yellow; pterothorax tinged with reddish.

Head slightly longer than wide; anterior portion with three pairs of small spines, one at anterior angle of eyes, the othere in a transverse row in front of eyes. Antennae less than twice as long as head; segment I concolorous with head, shorter than segment 2 , and provided with a prominant transverse carina; 2 brownish yellow, darkened laterally and basally; 3 blackish yellow; 4-8 blackioh brown; 3 and 4 each with a long, stout sense cone on outer surface. Mouth cone about .6 as long as head; maxillary palp1 three-segmented.

Prothorax faintly reticulate; posterior marging with about five pairs of short spines in addition to the prominent ones at the posterior angles. Fore coxâe projecting beyond the lateral outline of prothorax; fore femora swollen, reticulate apically, and with a sharp ridge separating the dorsal and lateral surfaces; fore tibiae very short (about .4 as long as femora), broader than long, prominently reticulate; fore tarsi slender. Tarsi, fore tibiae, and inner surface of fore femora yellow; rest of legs nearly concolorous with body.

Abdominal bristles as in . manicatus $\mathrm{H}_{a l i d a y ; ~ b a s a l}$ segments of abdomen with a transverse row of small, arcuate, chitonous thickenings at basal third.:

Measurements:- Total length $1.08 \mathrm{~mm}$; head, length $.11 \mathrm{~mm}$., width .10 mm.; prothorax, length .19 mm., width (excluding coxae) .23 mm.; mesothorax, width.29 mm.; abdomen, width .27 mm. Antennae: $1,31 \mu ; 2,27 \mu ; 3,26 \mu ; 4,24 \mu ; 5,24 \mu ; 6,32 \mu ; 7,13 \mu$; 8 , 13 in; total, . $19 \mathrm{~mm}$.

Male.- Length about .8 m. Color clear lemon yellow, excepting the last two abdominal segments, the five apical antennal segments, and the lateral surfaces of the femora and tibia of the middle and hind pair of legs, which are blackish brown. First antennal segment longer than the second, but without transverse carina.

Measurements:- Length .78 mm.; head, length $.090 \mathrm{~mm}$. , width, $.090 \mathrm{~mm}$; ; prothoras, length .17i mm., width (excluding coxầ) $.204 \mathrm{~mm}$.; mesothorax, width $.238 \mathrm{~mm}$.; abdomen, width .240 mm. Antennё: $1,28 \mu ; 2,25 \mu ; 3,25 \mu ; 4,25 \mu ; 5,21 \mu ; 6,28 \mu ; 7,11 \mu ; 8,7 \mu$; total .17 mm.

Described from two males and many females taken in sweeping from Bermuda grass (Capriola dactylon), at Matamoras and Montorey, Mexico, at Bromsville, Texas, and at Pulaski, Illinois, by Mr. Charles A. Hart.

This distinct and readily recognized species is not an uncommon one in sweepings from Bermude Grass, where $1 t$ seemingly replaces the dominant $\underline{C}$. manicatus of the north. 


\section{CALOTHRIPS gen. nov.}

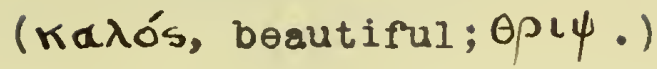

Head about as long as wide; vertex swollen, produced, overhanging and slightly surpassing base of antennae. Eyes prominent, protruding. Antennâ eight-segmented; style much shorter than segment 6; all sense cones simple. Maxillary palpi three-segmented. Prothorax distinctly longer than head and nearly as long as wide, broadest near base; posterior angles with two long spines, all other spines small and scarcely visible. Wings often lacking; when present, moderately broad, whout color pattern; fore pair with two longitudinal veins reaching nearly to tip; hind pair with a simple median vein; anterior margins of fore wings set with very long and slender spines which are scarcely distinguishable from the fringe.

Typo.- Calothrips cinctus sp. nov.

This genus is suggestive of Aptinothrips, Euthrips, and Rhaphidothrips. It strongly resembles the first in the produced vertex and in that the antennal sense cones are simple, as in Chirothrips, Limothrips, Heterothrips, Parthenothrips, and certain species of Heliothrips; but it differs most noticeably from the two described species of Aptinothrips in the much longer and stronger dorsal bristles. In this last respect, it approaches Euthrips, but in that genus the antennal sense cones are U- or V- shaped, the prothorax is wider, and the vertex is not swollen or produced. Its resemblance to Rhaphidothrips lies in a similarity of structure of the apical antennal segments, in the presence in both genera of two prominent bristles at the hind angles of the prothorax, and in the larger size of the apical abdominal bristles; it differs from that genus, however, in that the sixth an- 

tennal segment is longer than the seventh and eighth combined, and in that the sense cones are simple. 



\section{Calothrips cinctus sp. nov.}

Female.- Forma brachyptera. Length about $1.0 \mathrm{~mm}$. General color dark blackloh brown to black, with pterothorax, first abodomianl segment, intermediate antennal segments, and legs,yellow, slightly shaded with brown; prothorax often slightly paler than head.

Head about as long as wide, slightly shorter than prothorax; vertex swollen, produced anteriorly, broadly rounded as seen from above; dorsal surface faintly cross striate and armed with but two pairs of moderately long slender bristlies, the first pair of which Is situated opposite center of eyes and the second pair of which is placed slightly behind the inner posterior angle of the eyes. Eyes moderate in size, protruding. Ocelli lacking, or with the antorior one greatiy reduced or wanting. Antennâe moderately slender, about I.7 times as long as head; segments $l$ and 2 brown, the latter paler towards apex and at middle; $3-5$ pale yellow, sometimes slightly shaded with brown; 6-8 brown, concolorous with head; sense cones pale, slender, simple; formula $3,0-1 ; 4,0-1 ; 5,1-0 ; 6,1-1^{+1}$.

Prothorax blackish brown, very slightly broader than long and somewhat longer and wider than head; posterior angles each with two long, slender spines; anterior angles with a pair of smaller, weaker bristles, about equal in size to a posterior marginal pair; all other spines small and scarcely visible. Mesothorax slightly wider than prothorax, fore angles broadly rounded; metathorax closeIy united to mesothorax, and of about equal width throughout; mesoand mota-thoras uniform pale lemon yellow. Legs rather short and stout, yellow in color; femora and bases of tibiae often shaded with brown.

Abdomen moderately long, slender, distinctly broader than pterothorax; apex sharply conical, segment 10 with a longitudinal dorsel suture; spines on segments 9 and 10 long, strong, dark in color, and quite prominent. Segment 1 of abdomen pale yellow, concolorous with pterothorax; remainder of abdomen dark blackiah brown, concolorous with, or somewhat darker then, prothorax.

Measurements:- Length $1.02 \mathrm{~mm}$; head, length .135 mm., width $.140 \mathrm{~mm}$.; prothorax, length .158 mm., width .180 mm.; pterothorax,

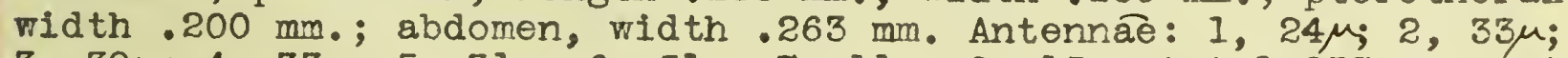
$3,39 \mu ; 4,33 \mu ; 5,31 \mu ; 6,51 \mu ; 7,11 \mu ; 8,15 \mu ;$ total.237 mm., width $.018 \mathrm{~mm}$.

Female.- Forma macroptera.- Length about $1.1 \mathrm{~mm}$. General color nearly uniform dark blacklsh brown, with pterothorax slightly paler and with legs and intermediate segments of antennê brownish yellow, the former shaded with brown or black.

Similar to forma brachyptera, but differing from it as follows: Ocelli always present, subequal in size, equidistant. Mesothorax diatictly broader than prothorax and metathorax; pterothorax

* Much as in the species of the genus Euthrips. 
concolorous with, or slightly paler than, remainder of body. Wings long; nearly attaining tip of abdomen, very pale in color, shaded with a light wash of bromish; fore wings with two longitudinal veins reaching nearly to tip; anterior vein with about nine pale briatles, usually two near apex, and about six or seven near base; posterior vein with about nine nearly equidistant similar bristles; hind wings paler than fore wings, with a single longitudinal vein. Legs often dark in color, the femora and tibiêe being shaded with black or brown.

First abdominal segment blackish brown.

Measurements:- Tength $1.14 \mathrm{~mm}$; head, length .128 mm., width . $141 \mathrm{~mm}$; prothorax, length. $164 \mathrm{~mm}$., width .186 mm.; mesothorax, width $.233 \mathrm{~mm}$; metathorax, width .203 mm.; abdomen, width

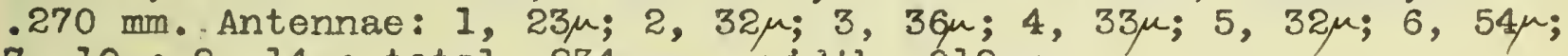
7 , $10 \mu ; 8,14 \mu ;$ total $.234 \mathrm{~mm}$, width .018 m.

Described from several specimens of both forms taken at Matamoras, Mexico, and Bromsville, Texas by Charles A. Hart; and at Grand Tower, Illinois, by Charles A. Hart and the writer.

The short winged form of this species is very striking and characteristic. In the field, the pale transverse band separates it at once from all members of its family with which it could possibly be confused. And in the laboratory, the microscope shows simple antennal sense cones, a broadly rounded produced vertex, long abdominal bristles on the last two segments, and two pairs of long bristles on the posterior angles of the prothorax-- a combination of cliaracters hitherto unknom. 



\section{Euthrips compositarum sp. nov.}

Female.- Length about $1.0 \mathrm{~mm}$. General color dark blackish brown to nearly black; tarsi and fore tibià yellowish; antennáe nearly concolorous with body.

Head nearly as long as wide, sides parallel; all spines short, inconspicuous; postocular bristles wanting. Antennầ stout, slightly. more than twice as long as head, of nearly equal length from base to style; segment 2 large, twice as long as $1 ; 3$ and 4 subglobose, subequal in length, the former with a very slender pedicel; 5 smaller and rather abruptly narrower than the preceding segment; 6 longest, about twice as long as style; style slender, its second segment slightly longer than its first. Antennal coloration: segments 1, 2 , and 4-8 concolorous with body, 2 slightly darkened at sides; 3 slightly paler at base.

Prothorax slightly longer than head; posterior angles each wi th two long spines, in addition to two slightly shorter pairs on the hind margin; anterior angles each with two short, inconspicuous spines; disk with several small scattered spines, of which an anterLor marginal pair is largest. Fore wings nearly uniformly clouded with brown, excepting a very small, longituainal, transparent area near base, just behind the anterior vein; anterior vein set with an unbroken series of about 18 spines; hind wings colorless, excepting for the brown longitudinal vein which reaches almost to tip. Legs nearly concolorous with body; fore tibiae shading to pale brownish yellow at apex; tarsi brownish yellow.

Abdomen scarcely wider than the pterothorax; spines slender, light brown; extreme posterior margin of segment 8 with a row of about ten very fine spines. 
Leasurements:- Length $1.05 \mathrm{~mm}$; head, length .11 mm., width .13 mm.; prothorax, length .12 mm., width .17 mm.; pterothorax, width $.225 \mathrm{~mm} . ;$ abdomen, width .225 mm. Antennäe: 1, $16 \mu ; 2,32 \mu ; 3,36 \mu$; $4,33 \mu ; 5,27 \mu ; 6,39 \mu ; 7,9 \mu ; 8,12 \mu$; total,.20 mm.; width .024 $\mathrm{mm}$.

Described from numerous females taken in flowers at Brownsville, Texas, by Charles A. Hart.

This little species is very closely related to Euthrips minutus Moulton, recently described from California.*

* Bulletín U. S. Bur. Ent., Technical series, No. 12, Part III, p. 56, PI. IV, figs. 32,33 . 

Female.- Length about $1.5 \mathrm{~mm}$. General color durk blackish brown to almost black, with a reddish cast, due to the presence of markoon hypodermal pigmentation; tarsi, apical half of tibiä of first pair, and intermediate antennal segments, yellow or yellowish.

Head somewhat longer than wide, broadest across cheeks; cheөks gently rounded, aub-parallel; vertex rounded, slightly produced, the anterior ocellus slightly overhanging; dorsal and lateral surfaces set with several short inconspicuous spines; post-ocular bristies pointed, nearly one third as long as head. Eyes slightly more than one third as long as head, not protruding. Ocelli anterior; posterior ocelli opposite anterior third of eyes. Antennâe about one and one-half times as long as head, moderately stout; segments 1 and 2 dark blackish brom, the latter paler toward apex and at middle; 3 yellow, shaded laterally with brow; 4-8 successively darker in color, ranging gradually from browish yellow to blackish brom; segment 3 subconical, swollen, noticeably narrower and shorter than segment 4; 4-6 sub-globose, pedicellate, the last truncated at apex; 7 oblong, pedicellate, truncate at apex, and broadly united to 8 , which is sub-conical; sense cones short, moderately stout, those on segments 3 and 4 blunt; formula: $3,0-1 ; 4,2-2 ; 5,1-1^{+1} ; 6,1-1$; 7 with one on dorsum near apex. Mouth cone blunt, about half as $10 n g$ as head, slightly surpassing middle of prosternim.

Prothorax a little more than two-thirds as long as head, and (including coxere) about 1.7 times as wide as long, surfaco nearly smooth; anterior marginal spines wanting, others blunt, the two pairs at the posterior angles longest. Pterothorax slightly wider than prothorax, about as broad as long, sides gently arcuate, slightly converging posteriorly. Wings present, clear; fore wings conspicue ously narrowed at middle, with a slight brownish clowd at extreme base, snd with the sub-apical fringe on posterior margin double for about seven halrs. Fore targi armed with a small acute tooth.

Abdomen slightly wider than pterothorax. Tube rather short, about .6 as long as head, and about twice as long as its basal width.

Measurements: Length, $1.5 \mathrm{~mm}$; head, length .200 mm., width $.171 \mathrm{~mm}$; prothorax, length. $150 \mathrm{~mm}$, width (including coxê) .266 mm.; pterothorax, width $.290 \mathrm{~mm}$; abdomen, width $.320 \mathrm{~mm}$.; tube, length $.117 \mathrm{~mm}$., width at base.057 mm., at apex .032 mm. Antennä: $1,33 \mu ; 2,39 \mu ; 3,37 \mu ; 4,42 \mu ; 5,39 \mu ; 6,36 \mu ; 7,36 \mu ; 8,25 \mu ;$ total. $29 \mathrm{~mm}$., width .029 mm.

Male.- Similar to female but slightly smaller (length about 1.2 mm.). Fore femora often swollen, and fore tarsi armed with a rather large, stout tooth. Abdomen slender.

Described from several specimens of both sexes, collected by Mr. Charles A. Hart, at Brownsville and homa, Texas, and at Matamoras, Mexico, in June and July, 1908. 

Genus LIOTHRIPS Uzel, 1895.

The following synopsis will aid in distinguishing the new species described below from all its known congeners. The characters of the species setinodis, hradacensis, and major have been drawn from their published descriptions, which in most cases are extremely vague and unsatisfactory.

A. Fore tibiä yellow.

a. Antennae yellow, their first and last segemnts dark. Head 1.2 times as long as wide. Scotland, Bohemia, England; in summer on leaves of oak and elm, and in winter in

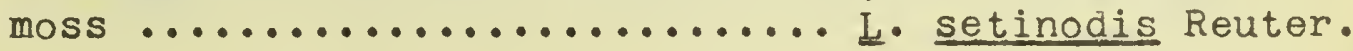

aa. All antennal segments excepting the third partially or entirely dark. Head about 1.3 times as long as wide. Middle and hind tibiâe black, abruptly yellow at tip. Bohemia; one specimen, on leaf of Heracleum sphondvilum. L. hradacensis Uzel.

B. Fore tibiâ nearly or quite concolorous with the body.

b. Head not more than 1.3 times as long as wice.

c. Length nearly $2.5 \mathrm{~mm}$.; fore tibiä brownish yellow in apical half. antennal segments 3 and 4 , and the basal halves of 5 and 6 orange-yellow; spines long, pointed; marginal abdominal bristles pale; tube .8' as long as head; subapical fringe on posterior margin of fore wings double for about nineteen hairs. A large clumsy species, occurring commonly on hickory in Illinois............. L caryge (Fitch).

cc. Length scarcely exceeding $2.0 \mathrm{~mm}$; fore tibiae black.

d. Antennâe with third segment abruptly lemon yellow, remainder of antenna dark blackish brown. Bristles long and pointed; marginal abdominal spines pale; tube .9 as long as head; subapical fringe on posterior margin of fore wings double for about fourteen hairs. Mexico; one specimen taken in sweepings.... L. varicornis sp. nov.

dd. Antennae with segments 3 and 4 entirely or largely yellow; 5 yellow in basal half; $6-8$ concolorous with body.

e. Forewings nearly black in basal half; head abbut 1.3 times as long as wide; eyes 

prominent; postocular and prothoracic bristles short and blunt; marginal abdominal bristles nearly black; tube .6 as long as head. Illinois ana Michigan; common on oak leaves..I. umbripennis (Hood).

ee. Fore wings brownish at extreme base; head about 1.15 times as long as wide; postocular and prothoracic bristles short and blunt; eyes less prominent than in the preceding species; marginal abdominal bristles yellowish; tube about .8 as long as head. Illinois; rare; in summer, on hickory, anü in

L. ocellatus Hood.

bb. Head about 1.5 times as long as wide.

f. Antennae lemon-yellow; head broadest across eyes, which arepulging; fore tibiae concolorous with body; postocular and prothoracic bristles short and blunt; marginal abdominal spines pale; tube about .7 as long

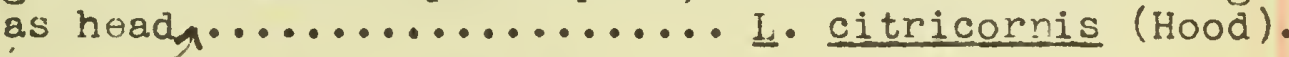

ff. Antennae yellow, both first and last s gments dark. Africa; one specimen; habitat not recorded......... L. major Buffa.

Illinois, Michigan, Pennsylvania; common on grape and hickory. 

Female.- Length about $2.1 \mathrm{~mm}$. General color dark blacklsh brown or black; tarsi, articulations of legs, aplces of antennal segments, and tip of tube paler; third antennal segment abruptly pale yellow.

Head about one and one fifth times as long as wide, broadest across cheeks; cheeks gently arcuate, slightly converging posteriorly; vertex elevated, produced, the anterior ocellus distinctly overhanging; dorsal and lateral surfaces finely transversely striate, set with several short inconspicuous spines; postoccular bristles pointed, about as long as eyes. Eyes large, finely faceted, not at all protmuding, one third as long as head. Ocelli anterior; posterior ocelli opposite anterior third of eyes; anterior ocellus overreaching insertion of antennae. Antennee twice as long as head, moderately slender; segments 1 and 2 nearly concolorous with body, 2 slightly paler toward apex and its middle; 3 pale yellow, slightly clouded apically; 4-8 nearly concolorous with body, slightly paler apically; segments 3-6 clavate, pedicellate; 7 oblong, pedicellate; 8 sub-conical; sense cones slender, colorless; formula: $3,0-1 ; 4$, $1-1^{+1} ; 5,1-1^{+1} ; 6,1-1^{+1} ; 7$ with one on dorsum near apex. Mouth cone acute, just attaining base of prosternum.

Prothorax two-thirds as long as head, and (including coxâ) about 2.3 times as wide as long; all spines present, moderately long, pointed, brown, the two pairs near the posterior angles longest; coxal spine straight, pointed, about equal in length to anterior marginals. Pterothorax slightly wider than prothorax, and somewhat wider than long; sides sub-parallel, slightly converging posteriorly. Wings long, closely fringed, not narrowed at middle; fore wings margined with a slight shading of brown, and with a narrow median brown bar, originaing just beyond the three basal spines and becoming obsolescent before apex of wing; sub-basal spines set in a narrow, dark brown longitudinal viłła; sub-apical fringe on posterior margin, double for about fourteen hairs; hind wings clear, with a median longitudinal vein extending about to middle. Legs rather stout, not long, for $\theta$ tarsi unarmed.

Abdomen large, slightly wider than pterothorax, tapering roundly from segment 6 to base of tube. Tubes about. 9 as long as head, twice as wide at base as at apex, tapering evenly its entire length. Abdominal bristles moderately long, pointed, pale; terminal bristles slightly shorter than tube.

Measurements:- Length $2.13 \mathrm{~mm}$; head, length .270 mm., width . $221 \mathrm{~mm}$; prothorax, length $.180 \mathrm{~mm}$., width (including coxâe) $.405 \mathrm{~mm}$.; pterothorax, width $.465 \mathrm{~mm}$.; abdomen, width $.510 \mathrm{~mm}$; tube, length .248 mm., width at base $.096 \mathrm{~mm}$., at apex, .048 mm. Antennâ: $1,39 \mu ; 2,60 \mu ; 3,87 \mu ; 4,78 \mu ; 5,75,-; 6,68 \mu ; 7,63 \mu ; 8,41 \mu$; total, .511 mm.; width at segment $4, .041 \mathrm{~mm}$.

Described from one female, taken in sweepings from grass and weeds, at Monterey, Mexico, July 5, 1908, by Charles A. Hart. 



\section{Phloêthrips vittatus sp. nov.}

\section{Female.- Unknown.}

Male.- Length about $2.2 \mathrm{~mm}$. Dorsal surface closely reticulate, non-shining; ventral surface smooth. General color (by reflected light) dark mahogany brown, with a narrow, latero-dorsal white stripe extending along the sides of the prothorax and abciomen, terminating on the seventh abdominal segment; this stripe is about as wide as the antenna, and is interruptea only on the pterothorax, where it is entirely wanting. General color (by transmitted light)yellowish brown, with maroon hypodermal pigmentation; legs and tube blackish brown, non-pigmented; antennae nearly concolorous with boày, intermediate segments yellowish at base and at apex.

Head about 1.2 times as long as wide; dorsal and lateral surfaces closely and strongly reticulate, with several moderately prominent spiniferous tubercles, of which those on the cheeks and four near center of dorsum are especially noticeable; cheeks subparallel, converging rather abruptly to the eyes; posterior bristles lacking. Eyes moderately large, finely foceted, contained in lengthatwo and one-half times, and slightly narrower than their interval. ocelli subapproximate, opposite center of eyes. Antennâe five-thirds as long as head; segments 3-5 clavate, abruptly narrower apically, urnor vase-shaped; 6 and 7 clavate, sharply conical; sense cones large, moderately slender; formula:* $3,1-2 ; 4,1-2^{+1} ; 5,1-1^{+1} ; 6,1-1^{+1}$; 7 with one on dorsum near apex; segments 1 and 2 nearly concolorous with body; $3-5$ blackish brown, pale at apex, and with their basal

* The explanation of the formula for the antennal sense cones has been given in Ann. Ent. Soc. Am., Vol. I, No. 4, p. 285, and in Ent. News, Vol. XX, No. 1, p. 29 , footnote. 

two-fifths brownish yellow; 6-8 dark blackish brown, 6 with pale pedicel. Mouth cone pointed, nearly attaining base of prosternum.

Frothorax threo-fourths as long as head, and incluaing coxâ, about 1.8 times as wide as long; all usual spines present, dilated apically, the outer pair at the posterior angles longest, twice as long as the coxal and the anterior angular pairs. Pterothorax slightly wider than long and broader than prothorax; sides nearly straight, slightly converging posteriorly. Wings long, nearly attaining tube, not narrowed at middle, closely fringed, veinless; subapical fringe on posterior margin of first peir double for about twenty hairs. Legs normal; fore femora not swollen, about half as wide as head; for $\theta$ tarsi armed each with a short, characteristically shaped tooth (see figure).

Abdomen moderately slender; segment 9 long, about equal to tube in length, nearly circular as seen from above. Tube about five-sixths as long as head, tapering evenly from base to apex; terminal bristles nearly as long as tube. Marginal bristles short, capitate, colorless.

Measurements:- Total length $2.18 \mathrm{~mm}$.; head, length $.30 \mathrm{~mm}$., width . $25 \mathrm{~mm} \cdot$; prothorax, length .23 mm., width (including cox $\widehat{\theta e}$ ) $.41 \mathrm{~mm} \bullet$; pterothorax, width.44 mm.; abdomen, width $.45 \mathrm{~mm} . ;$ tube, length $.23 \mathrm{~mm}$, width at base $.09 \mathrm{~mm}$., at apex $.045 \mathrm{~mm}$. Antennâe: $1,39 \mu ; 2,57 \mu ; 3,99 \mu ; 4,87 \mu ; 5,81 \mu ; 6,57 \mu ; 7,54 \mu ; 8,33 \mu ;$ total .507mm., width 41 .

Described from two macropterous males, taken by the writer on a rotting poplar stump, near Baldwin, Michigan, August 17, 1908.

The peculiar coloretion of this insect distinguishes it at once from all other species of its genus. Its resemblance, however, both in coloration and structure, to the species of Acanthothrips is striking. The principal characters of that genus are, of course, the 

presence in both sexes of a subapical tooth on the fore femora, and the urn- or vase-like form of the intermediate antennal segments. Phloothrips vittatus, though lacking the femoral tooth of Acanthothrips, possesses an antenna strikingly similar to that of A. nodicornis Reuter, and in coloration is strongly suggestive of A. albivittatus $m$. It might be said that if the division between Fhlooothrips Haliday and Acanthothrips Uzel were based on any other character than the presence or absence of an acute tooth on the anterior femora, this insect would fall in the latterathan in the former genus. 

Male.- (Brachypterus).- Length about $2.3 \mathrm{~mm}$. Color uniform black; surface shining.

Head sub-angular, 1.7 times as long as wide, truncate in front; cheeks sub-parallel, excepting for an abrupt, collar-like, basal wioening about $.04 \mathrm{~mm}$. In length; dorsal and lateral surfaces faintly transversely striate, set with a few short, rather stout spines which are not raised on tubercles, and of which there is a longer and stronger pair near middle of dorsum and two pairs on the lateral outline at the basal and apical thiras, respectively; two pairs of small, inter-ocular spines, one just behind the posterior ocelli, the other near anterior angle of eye; post-ocular bristles pointed, about as long as eyes. Eyes small, not protruding. Ocelli moderately large, their diameter about twice as great as that of facets of eyer; posterior ones widely separated, nearly contiguous to margins of eyes; anterior ocellus situated on vertex, directed forwards and upward. Antemae slightly less than twice as long as head, not inserted behind vertex; segments $3-b$ claviform, elongate, 3 nearly five times as long as greatest sub-apical width; 6 and 7 oblong, pedicellate; 8 sub-conical; sense cones short, acute. Mouth cone broadly rounded at apex, reaching beyond midale of prosternum.

Prothorax about .6 as long as head, and (including coxâe) almost twice as wide as long, surface nearly smooth; anterior angles produced into a strong, short, tooth-like projection about $.017 \mathrm{~mm}$. in length; posterior angles with three distinct sclerites; usual spines all present, the two pairs at the posterior angles much the longest, about as long as the post-oculars, the others about as long as those on clubs; fore coxâ armed with a single rather short spine; Pterothorax slightly narrower than prothorax, sides sub-parallel. Wings reduced, .7 as long as head, slightly less than flve times as long as wide. Legs very long; spines short, slender; inconspicuous; fore femora very large, longer than and .7 as wide as head, and about three times as long as wide; fore tarsi armed with a long, slenter, straight tooth, nearly as long as eye.

Abdomen slender, slightly narrower than prothorax; sides sub-parallel to sixth segment, thence tapering to base of tube; slightly shorter than head, expanded in basal and sixth and narrowea at apex, intermediate portion parallel-sided; terminal bristles weak, two-fifths as long as tube. Abdominal bristles pointed, long and strong, those on segment 9 nearly as long as tube.

Measurements:- Length $2.27 \mathrm{~mm}$.; head, length, .40 mm., width $.24 \mathrm{~mm}$.; prothorax, longth .25 mm., width (including coxê) .47 mm.; pterothorax, width.42 mm.; abdomen, width. $45 \mathrm{~mm}$; ; tube, length . 37 $\mathrm{mm}$. , width at base, $.102 \mathrm{~mm}$., wiath at apex, $.048 \mathrm{~mm}$. Antennae: 1, $69 \mu ; 2,72 \mu ; 3,174 \mu ; 4,129 \mu ; 5,108 \mu ; 6,78 \mu ; 7,72 \mu ; 8,42 \mu ;$ total .74 mm., width $.036 \mathrm{~mm}$.

Described from one short-winged male, taken on huisache (Acacia farnesiana Willd.), in the South Texas Garden, Brownsille, Texas, June 27, 1908, by Mr. Charles A. Hart. 

Male. ( Macropterous).- Length sbout $2.4 \mathrm{~mm}$. Color uniform black. Surface shining.

Head sub-rectangular, 1.7 times as long as wide, truncate in front; cheeks parallel, excepting for an abrupt collar-like basal widening about $h a f(I)$ as long as eye; dorsal and lateral surfaces faintly transeversely striate; cheeks each with two rather stout spines bt basal and apical thirds, respectively; middle of dorsum with a pair of small slender spines; two palrs of small interocular spines, one fust behind posterior ocelli, the other near anterior angle of eyes and pointing directly forward; postocular bristles pointed, about as long as eyes. Eyes small, not protruding. Ocelli moderately large, their diameter about twice as great as that of facets of eyes; posterior ones widely separated, contiguous to margins of eyes; anterior ocellus situated on extreme vertex, slightly overhanging, and pointing directly forward. Antennâe slightly more than twice as long as head, inserted beneath vertex; segments 3-5 claviform, elongate, 3 slightly more than four times as long as its greatest sub-apical width; 6-7 oblong, pedicellate; 8 sub-conical; sense cones short, acute. Mouth cone broadly rounded at apex, reaching beyond middle of prosternum.

Prothorax nearly .7 a.s long as head, and (including coxāe) somewhat less than twice as wide as long, surface nearly smooth; anterior anglos acute, scarcely prolonged; posterior angles with three sclerites, the posterior two of which are more or less fused with each other and with the notum; usual spines all present, the two pairs at the posterior angles much the longest, about as long as the postoculars, the others scarcely visible, shorter than those on cheeks; fore coxae armed with a single short spine. Pterothorax slightly wider than prothorax, sides slightly arcuate. Wings long, closely fringed. Legs moderately long, without prominent spines; fore femora about as long as head and twice as long as wide; fore tarsi armed with a long slender tooth about half as long as eyes.

Abdomen slender, but distinctly wider than prothorax; sides sub-paraliel to sixth segment, thence tapering to baise of tube; tube olightly longer than head, expanded in basal sixth, thence tapering very gradually to near apex, which it is rather abruptly narrowed; terminal bristles weak. Abdominal bristles pointed, long and strong, those on segment 9 nearly as long as tube.

Measurements:- Length $2.36 \mathrm{~mm}$; head, length . $34 \mathrm{~mm}$, width $.22 \mathrm{~mm}$; prothorax, length .23 mm., width (including coxâ) .42 mm.; pterothorax, wiath $.45 \mathrm{~mm}$; abdomen, width $.47 \mathrm{~mm}$; tube, length .36

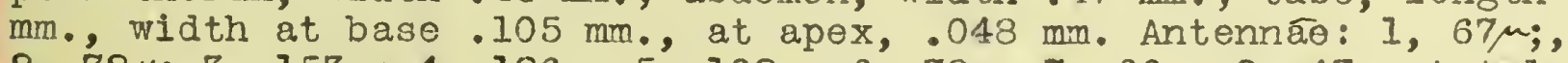
$2,72 \mu ; 3,153 \mu ; 4,126 \mu ; 5,102 \mu ; 6,78 \mu ; 7,66 \mu ; 8,47 \mu ;$ tota1. 71 $\mathrm{mm}$., width $.036 \mathrm{~mm}$.

Described from one long-winged male, grass, in the South Texas Garden, Brownsville, Texas, June 27, 1908, by Mr. Charles A. Hart. 

* * * * * * * * $*$

$* * * 1 \quad *$

* $*$ * I

*

*

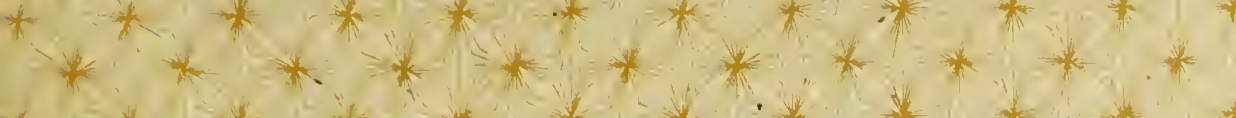

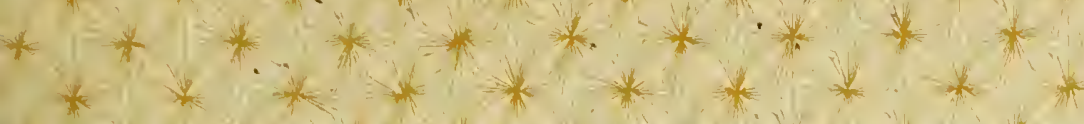

* * * * * * * * * * * * * * * * *

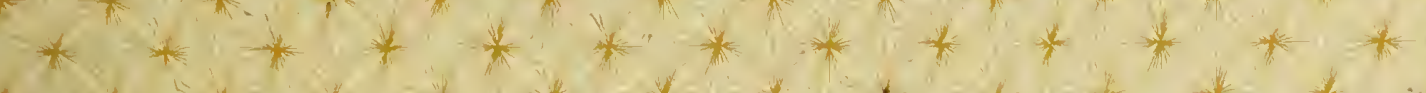

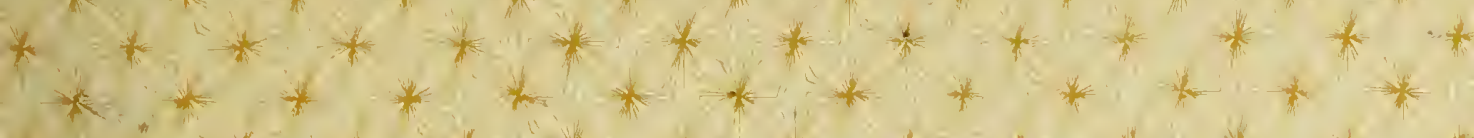

* * * * * * * * * * * *

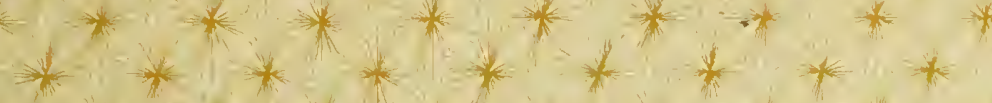
$*+* * * *+\ldots+\cdots$ $* * * * * * * * * * * *+*$

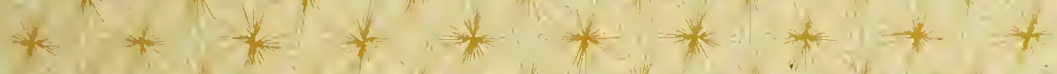
$* * * * * * * * * * *+* *$ * * * * * * * * * * * * *

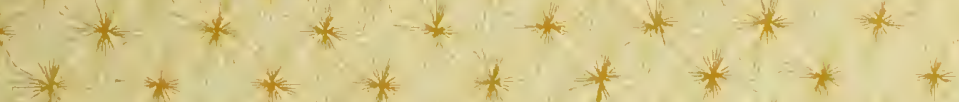
* $* * *+*+1$

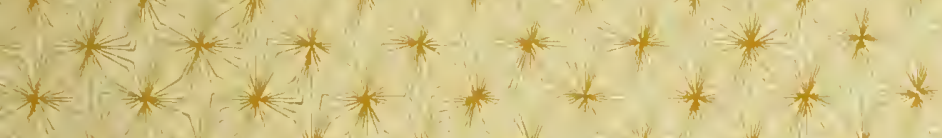

$* * * * * * * * * * * * *+$

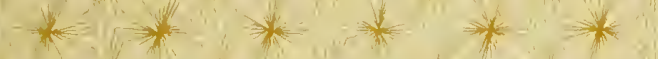

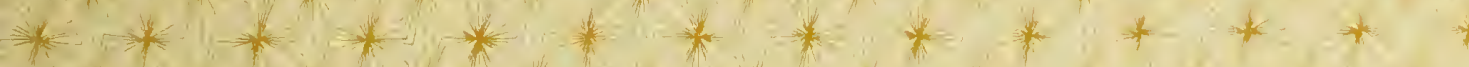

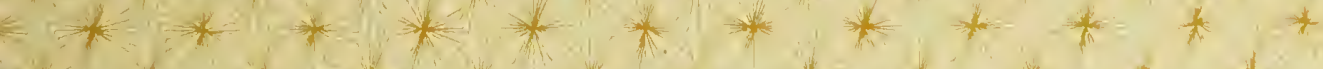
$* * * * * * * * * * * * *$

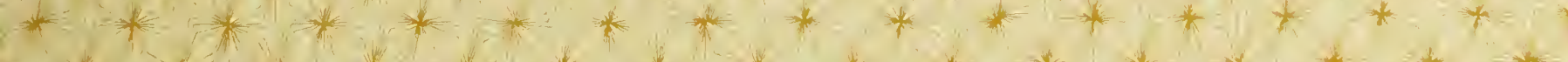

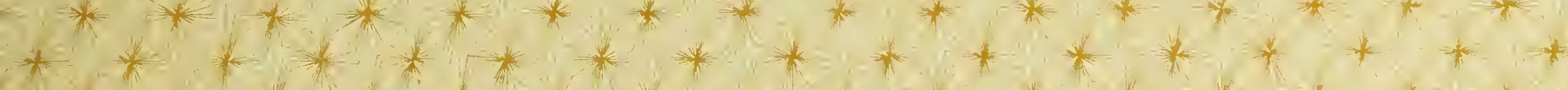

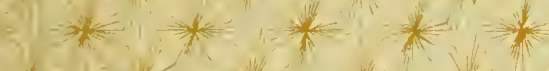

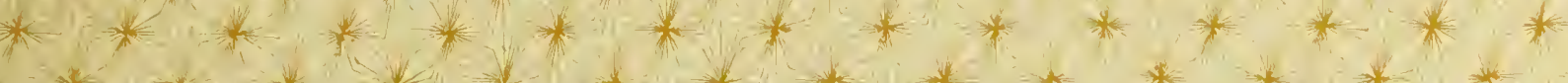

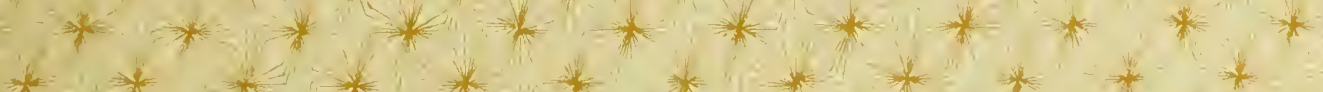
* * * * * * * * * * * * * * * * * *

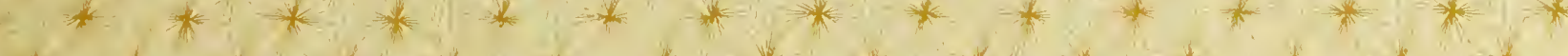
$* * * * * * * * * * * * * * * * *+*$

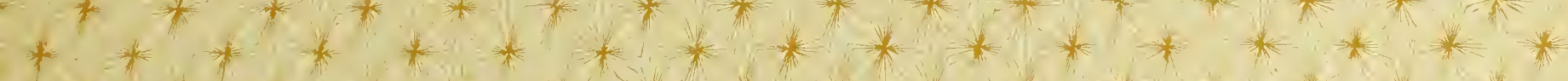

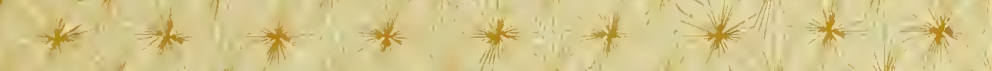
*** * * * * * * * * * * * * * * * 
